\title{
15
}

\section{Between Economics and Education: How International Organisations Changed the View on Education}

\author{
Dennis Niemann, David Krogmann, \\ and Kerstin Martens
}

\section{Introduction}

In September 2018, the World Bank released its annual World Development Report titled "Learning to realize education's promise". What made this report special was that it put the topic of education at its centre for the first time in the history of the Bank's flagship publication. The World Bank underscored that education is of utmost importance to secure the economic development of states and that targeting education policies is considered one of the key tasks of the international organizations (IOs). Almost two decades earlier, the Organisation for Economic Co-operation and Development (OECD) published its first Programme for International Student Assessment (PISA) study in 2001 and successively advanced to become one of the most influential IOs in the field of education by gaining regulatory governance in the field (Martens and

D. Niemann $(\bowtie) \bullet$ D. Krogmann $\bullet$ K. Martens

University of Bremen, Bremen, Germany

e-mail:dniemann@uni-bremen.de; krogmann@uni-bremen.de;

martensk@uni-bremen.de

(C) The Author(s) 2022 
Jakobi 2010). National education systems respond to new challenges posed by IOs, such as the OECD or the World Bank, in order to keep pace with a constantly growing knowledge society that views education as the key to growth and prosperity.

Interestingly, neither the World Bank nor the OECD was originally mandated to deal with education. Both IOs were primarily concerned with economic growth and development. However, at some point in time, they realised that in order to fulfil their original tasks they would also have to address the field of education. So, how did it come about that economic-centred IOs expanded into education? Are the World Bank and the OECD simply two prominent exceptions or can we observe a general pattern of IOs with a background in economic development policies (or any other non-education related issue areas) expanding into education topics? If that is the case (spoiler alert: it is the case!), what does it mean for the framing of education in the international community?

In this chapter, we show how the vertical interdependence regarding the communication of ideas spread by IOs is increasingly manifested. We trace the general development of the IO population in the policy field of education to underscore that IOs whose mandates were not originally concerned with education entered the field of education. In this context, particularly IOs with economic policy backgrounds expanded into education policy. In the second step, we illustrate how these economic IOs changed the way education is viewed today and which ideas regarding education dominate in global discourse, as exemplified by the cases of the World Bank and the OECD.

\section{The Continuous Expansion of Education IOs}

In the wake of ongoing globalisation processes and worldwide competition, education policy has become progressively internationalised over the last decades. IOs are now seen as significant actors in the education sector, being responsible for analysing policies and practices, making recommendations, providing normative guidance, and establishing 
networks with like-minded actors. While education has always been a relevant issue for some IOs based on their mandate, others adopted the topic rather gradually for various reasons. Obviously, the United Nations Educational, Scientific and Cultural Organization (UNESCO) is the prime example of an $\mathrm{IO}$ actively promoting education ideas since its inception in 1945 as part of the UN system. But even before UNESCO was founded, the International Labour Organization (ILO) emphasised the social significance of education. All in all, there are about thirty IOs today that can be considered as dealing with education policy issues (Niemann and Martens 2021). ${ }^{1}$

However, these IOs in education policy also exhibit several different characteristics. Roughly one-fourth of them envision education as a primary activity, in other words, these organisations were founded with the intended purpose of focusing mainly, or sometimes even solely, on education topics. From their inception onward, their main issue area has always been education and most of them had already been founded between 1966 and 1975. These distinct education IOs stand in contrast to a majority of IOs that cover several policy fields, with education being only one among other issues they deal with. This pool comprises two subtypes. On the one hand, it is constituted by general IOs, in other words, IOs that have a broader purpose and focus on a wide range of issue areas over a number of fields. Examples include the European Union (EU) and the South Asian Association for Regional Cooperation (SAARC). Although several of them embraced education topics from the very beginning, many of them moved into the policy field at a later stage, at times even quite long after their inception, making education part of their programmatic mission ex-post. The group of IOs in education policy is also composed of specialised IOs which have a primary mission other than education, like the United Nations High Commissioner for Refugees (UNHCR) or the ILO, which first and foremost focus on refugee

\footnotetext{
${ }^{1}$ By education IO, we refer to "public" organisations in which states are the principal members. That excludes NGOs, like the Gates Foundation or the Global Partnership for Education. We count IOs which are listed in either the Yearbook of International Organizations or the Correlates of War data set and which mention education in the IO's programmatic mission statement as a designated task of the IO (be it in the IO's preamble, founding treaty, amended treaties, or on its current websites), have their own permanent organisational (sub-) department, and address education policy issues.
} 
protection and labour rights respectively. Economic IOs, like the OECD or the World Bank, also fall into this group of specialised IOs.

Generally, what we can observe is a steady rise in the number of IOs concerned with education topics after World War II (see Fig. 15.1). Several IOs discovered education as an elemental policy field for pursuing their overall mission. In particular, we find that IOs with a mandate related to financial issues transitioned into education issues as early as the 1960s/1970s. Surprisingly, and in contrast to what is widely assumed, this development predates the emergence of the global knowledge society, the internationalisation of discourse around education policy and the diversification of relevant actors in the field. Hence, IOs were not the effect of intensified internationalisation in education policy but rather the drivers of this development. At what point then did these derivative IOs consider education crucial enough to be included into their catalogue of activities after their inception?

Empirically, a number of general trends can be identified in the population of education IOs over the last seventy years. These trends are displayed in Fig. 15.1. Overall, the number of IOs working in education policy increased from a mere two organisations in 1945, namely the ILO and UNESCO, to thirty organisations in 2018. Interestingly, the course of this expansion is rather steady. Over the decades, the population of

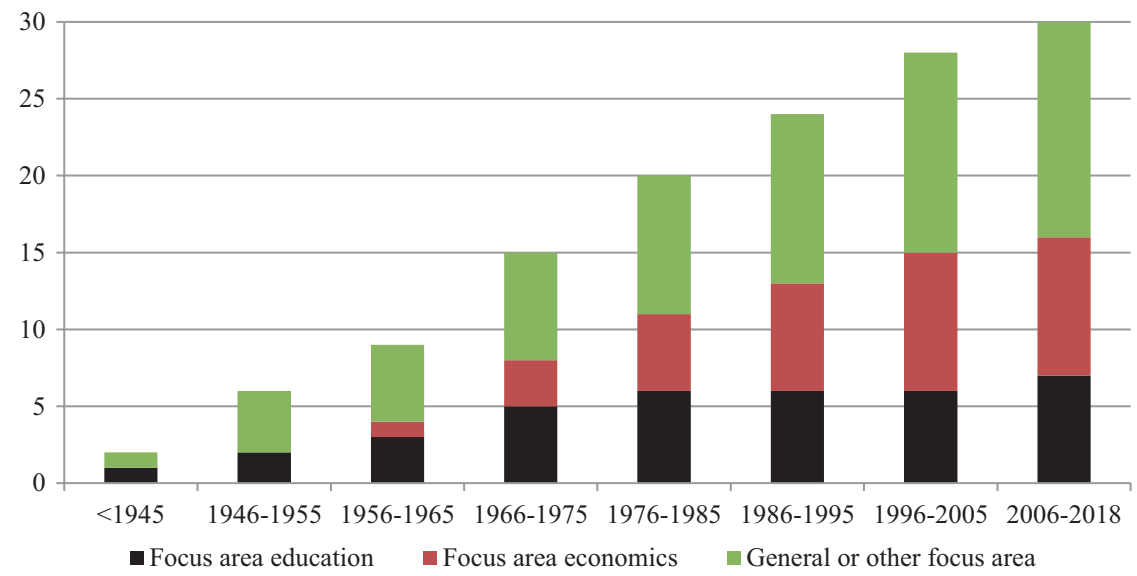

Fig. 15.1 Growth of education IOs over time 
education IOs expanded incrementally, with no particular sharp turns at any point in time. By the mid-1990s, this expansion had slowed down and settled toward the end of the decade, with only two education IOs being founded after 2005. This finding suggests that after a continuous growth or discovery of education as a significant field of IO activity over the last decades, the field is now saturated.

In and of itself, this development is not surprising. Given a rising number of existing IOs, a parallel increase in IOs which deal with education policy should be expected. What is most striking about the data, however, is the fact that the internationalisation of the field of education seems to have started earlier than what is commonly assumed in the literature. Generally, research on the internationalisation of education presumes that the process began in the 1990s. Indeed, education increasingly and undeniably became a prominent policy issue in the late 1990s, as exemplified by the rise of international large-scale assessments like PISA. However, the involvement of IOs in education policy seems to have started much earlier, as shown above.

A closer look reveals that IOs with an original mandate in the field of economic policy have become the most important subgroup in education policy today: They cover almost one-third of the entire education IO population. Some of them have even become key players in international education policy. Most notably, a number of development banks now work on education. Our analysis underscores that education has become increasingly important over time for economic IOs, as education topics were linked to their original aims. This is especially noteworthy because economic IOs started including education policy in their programmatic missions somewhat more recently than other education IOs. Figure 15.1 shows that general IOs as well as specialised IOs which are not concerned with economic policy started to address education policy earlier than economic IOs. Economic IOs were latecomers, only starting to concern themselves with education policy around the late 1960s to mid-1970s. In the decade from 1956 to 1965, only one of five existing economic IOs in the reviewed sample engaged in education policy (see Fig. 15.2). By 1975,50 percent of economic IOs dealt with education policy and by 1996, all nine economic IOs had included education in their portfolios. 


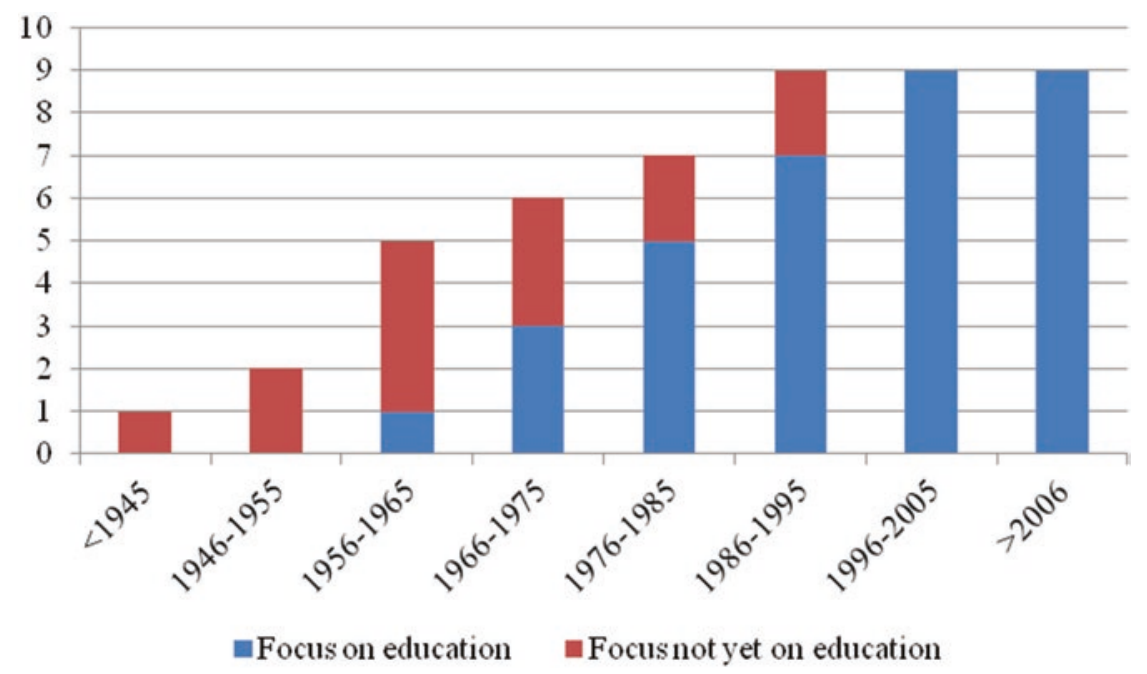

Fig. 15.2 Economic IOs in the field of education

\section{The Impact of Economic IOs Entering the Education Field}

Although they came late, economic IOs have strongly influenced the view on education. The main story of economic IOs discovering education policy is that they started their activities in the field of education with a certain understanding of the purpose of education. Economic IOs particularly pointed out that improvements in education positively affect the development of a state. In particular, the established links between economic development and well-being, human capital generation, and education skills propelled economic IOs toward the education arena. Education improvements were recognised as an investment. The World Bank and the OECD will serve as exemplary cases here. For both IOs, an ideational view on education purpose is overshadowed by the utilitarian economic perspective.

While the World Bank's concrete foci of development policies in education varied over time, its primary mission of providing development aid in order to reduce poverty and foster human development remained 
constant. Since the World Bank is also a conventional bank that grants financial aid, borrowing countries have to implement certain policies and adopt the defined framework of education advanced by the Bank (SteinerKhamsi 2012). Against this background, the Bank's discourse on education can be characterised alongside key ideas which revolve around a utilitarian understanding of education.

The World Bank's economic focus became institutionalised in its education programme in the 1960s. By addressing the "engineering problem" (e.g. skilled staff was required to operate new technology), the development of human capital was prioritised over capital goods (Heyneman 2003). The "Washington Consensus" was of particular importance in framing the Bank's education policy agenda of utilitarianism: reduce public sector spending, liberalise markets, and privatise public enterprises. With the rise of the neoliberal paradigm in the 1980s, this view was further strengthened and the economic IOs pushed for the introduction of more market mechanisms in the education sector. From 1980 onward, the World Bank together with the OECD strongly promoted the neoliberal Chicago School's preference for a global free market (Robertson 2012). This triggered a twofold development: Economic IOs sought to optimise education policies and states sought the advice of economic IOs in matters of education. In consequence, some economic IOs became key players in education. Even when the neoliberal trend in global social policy came to a partial halt in the 1990s and a "PostWashington Consensus" began to emerge, the Bank's education ideas were still in line with neoclassical economic thinking (Mundy and Verger 2015). However, the Bank gradually widened its view to include noneconomic ideas, developing a more holistic position in regard to the purpose of education.

Although the Bank nowadays emphasises education as a human right (World Bank 1999, 2018) and recognises the limits of the market model for education (Robertson 2012), the purpose of education as seen in the Bank's discourse makes clear that an economic leitmotif prevails. The utility of education is still brought to the fore. The Bank's "Education Strategy 2020" of 2011 still reflects an economic paradigm in education and promotes the global standardisation of curricula, private-public education partnerships for designing and conducting education projects, and 
the decentralisation of national education systems (Enns 2015). In the view of the Bank, education affects how well individuals, communities, and nations fare, and countries need more highly educated and skilled populations. Moreover, individuals need more skills to become more productive, to compete, and to thrive in a global labour market (World Bank 1999). The level of acquired "skills in a workforce (...) predicts economic growth rates of a states" (World Bank 2011,3) and learning is essential for human capital development (World Bank 2018).

Taken together, the utilitarian-driven view on education was always central to the Bank's education discourse: Education should serve the purpose of fostering the economic development of states and societies. However, the notions changed from viewing education as instrumental for training technicians, to a strict neoliberal human capital approach, to the rather holistic and evidence-based understanding of education which emphasises the positive effects that high-quality education can have on economic and social development. Currently, the economic view is still central but embedded in a broader framework that also includes aspects of social cohesion and individual fulfilment. The economic core of the Bank's education belief system became supplemented with other, more holistic views on education. However, other views are linked (and subordinated) to an economic reasoning, namely one that emphasises a return on investment.

A similar pattern can be identified when examining the education ideas that the OECD promotes. In its early years, the OECD's education endeavours reflected the fundamental task of improving its member states' (scientific and commercial) performances in the face of pressing challenges at that time: the reconstruction of Europe, economic stabilisation, and increasing confrontation with the Soviet Union (Woodward 2009). From the early 1960s to the mid-1970s and under the leading paradigm of Keynesianism, the emphasis of the OECD's education activities progressively shifted toward social and equity objectives and became closely linked to issues related to the labour market and economic growth (Papadopoulos 2006). In the mid-1970s, the OECD again turned its attention to education as an essential generator of economic growth. In this phase, the social and equity components of education policy "receded to the background, giving way to economic concerns" (Papadopoulos 
2006, 25). In the 1980s, the neoliberal interpretation of education was further strengthened since the OECD focused on "how to adjust education to changing economic requirements in the context of stagnating budgets" (Mundy 2007, 28) and moved to a neoclassical supply-side orientation. Social and equity concerns were dominated by utility considerations. Since the mid-1990s, the OECD proactively worked on strategies that dealt with developing human capital to counteract the negative effects of globalisation (OECD 1996). Education was defined as a driving force for growth and development, and the OECD was committed to improving the quality of their member countries' education systems (OECD 2010-2011).

In terms of the OECD's ideas, the advancement of education systems should contribute first and foremost to human capital formation and secondarily to the progress of social citizenship (Robertson 2005). The OECD views human capital as "a major driver of a country's trend productivity, not least through its impact on innovation" (OECD 2010, 18). However, the OECD does not neglect the wider social aspect of education and has stated that education serves the provision of social cohesion and overall well-being, including health issues for example (OECD 2007). Remarkably, social cohesion refers to economic factors: In order to create more social cohesion, education should enable individuals to advance economically. National education systems "need to equip people with knowledge, skills and tools to stay competitive and engaged" (OECD 2010-2011, 3). The findings of the OECD's infamous PISA analysis confirm the positive returns on employment, earnings, wellbeing, and contributions to society for the individual as well as for the economy at large. Education was meant to provide support for the economy and the economy is responsible for securing and fostering the wellbeing of the whole society. Concerning this matter, social dimensions were also included in the OECD's leitmotif of education, however, under an economic-centred framework. 


\section{Conclusion}

Our study shows an increase in the total number of IOs active in the field of education and a particular increase in economic IOs that discovered the field of education at some point after their inception. Thus, vertical interdependencies between states in the education field have become denser over time. These transnational developments with respect to IOs and their impact on education are surprising, especially since education has long been seen as a field intimately connected to the (nation) state for most of recent history.

The stories of the World Bank and the OECD show that IOs with an economic background expanded into the field of education. They also show that these IOs came with a certain idea of the purpose of education, one in which the importance of skill formation through education for economic development is emphasised over other more holistic purposes. This interpretation of education challenged IOs with opposing views, like UNESCO and the ILO, and stirred competition. Moreover, because the World Bank and the OECD deployed massive resources in their education programmes, they often overshadowed other IOs. At the same time, the economic IOs' ideas on education became universally transmitted and accepted by national stakeholders. In consequence, the international education landscape significantly changed and new ideas about the purpose of education shaped national reforms.

Economic IOs, which moved into education much later than other IOs, were already established actors in the field by the early 1990s. In that sense, the activities of IOs in education policy precede the attempts made by nation states to internationalise the standards of their education system. Thus, when it comes to education policy, it seems fair to say that the creation of IOs and the delegation of tasks related to education policy were not an effect of an ever more globalised world. Instead, IOs were a driving force behind this specific aspect of globalisation.

Acknowledgements This chapter is a product of the research conducted in the Collaborative Research Centre "Global Dynamics of Social Policy" at the University of Bremen. The centre is funded by the Deutsche Forschungsgemeinschaft (DFG, German Research Foundation)—project number 374666841-SFB 1342. 


\section{References}

Enns, Charis. 2015. Knowledges in Competition: Knowledge Discourse at the World Bank during the Knowledge for Development Era. Global Social Policy 15 (1): 61-80.

Heyneman, Stephen P. 2003. The History and Problems in the Making of Education Policy at the World Bank 1960-2000. International Journal of Educational Development 23 (3): 315-337.

Martens, Kerstin, and Anja P. Jakobi. 2010. Expanding and Intensifying Governance: The OECD in Education Policy. In Mechanisms of OECD Governance. International Incentives for National Policy Making? ed. Kerstin Martens and Anja P. Jakobi, 146-163. Oxford: Oxford University Press.

Mundy, Karen. 2007. Educational Multilateralism-Origins and Indications for Global Governance. In New Arenas of Education Governance. The Impact of International Organizations and Markets on Educational Policy Making, ed. Kerstin Martens, Alessandra Rusconi, and Kathrin Leuze, 19-39. Basingstoke: Palgrave Macmillan.

Mundy, Karen, and Antoni Verger. 2015. The World Bank and the Global Governance of Education in a Changing World Order. International Journal of Educational Development 40 (1): 9-18.

Niemann, Dennis, and Kerstin Martens. 2021. Global Discourses, Regional Framings and Individual Showcasing: Analyzing the World of Education IOs. In International Organizations in Global Social Policy, ed. Kerstin Martens, Dennis Niemann, and Alexandra Kaasch, 163-186. Cham: Palgrave Macmillan.

OECD. 1996. Measuring What People Know. Human Capital Accounting for the Knowledge Economy. Paris: OECD Publishing.

- 2007. Understanding the Social Outcomes of Learning. Paris: OECD Publishing.

Publishing. 2010-2011. Work on Education. Paris: OECD Publishing.

Papadopoulos, George. 2006. The OECD and the Evolution of National Policies for Education, 1960-1990: An Overview. In Supranational Regimes and National Education Policies_Encountering Challenge, ed. Johanna Kallo and Risto Rinne, 21-26. Turku: Finnish Educational Research Association. 
Robertson, Susan L. 2005. Re-imagining and Rescripting the Future of Education: Global Knowledge Economy Discourses and the Challenge to Education Systems. Comparative Education 41 (2): 151-170.

2012. The Strange Non-Death of Neoliberal Privatization in The

World Bank's Education Strategy 2020. In The World Bank and Education:

Critiques and Alternatives, ed. Steven J. Klees, Joel Samoff, and Nelly P. Stromquist, 189-206. Rotterdam: Sense Publishers.

Steiner-Khamsi, Gita. 2012. For All by All? The World Bank's Global Framework

for Education. In The World Bank and Education, ed. Allan Pitman, Vandra

Masemann, and Miguel A. Pereyra, 3-20. Rotterdam: Sense Publishers. Woodward, Richard. 2009. The Organisation for Economic Co-operation and Development (OECD). London: Routledge.

World Bank. 1999. Education Sector Strategy. Washington, DC: World Bank. 2011. Learning for All: Investing in People's Knowledge and Skills to

Promote Development. World Bank Group Education Strategy 2020. Washington, DC: World Bank.

-2018. Learning to Realize Education's Promise. World Development Report 2018. Washington, DC: World Bank.

Open Access This chapter is licensed under the terms of the Creative Commons Attribution 4.0 International License (http://creativecommons.org/licenses/ by/4.0/), which permits use, sharing, adaptation, distribution and reproduction in any medium or format, as long as you give appropriate credit to the original author(s) and the source, provide a link to the Creative Commons licence and indicate if changes were made.

The images or other third party material in this chapter are included in the chapter's Creative Commons licence, unless indicated otherwise in a credit line to the material. If material is not included in the chapter's Creative Commons licence and your intended use is not permitted by statutory regulation or exceeds the permitted use, you will need to obtain permission directly from the copyright holder. 